\title{
Irrigation of Dry Hill Sal Areas in India
}

T HIS subject is discussed by Mr. W. P. M. Warren in the Indian Forester of April of last year. Those who have had an acquaintance witl the considerable areas of poor open decrepit forest which cover the hills in what was formerly known as Chota Nagpur in the old Bengal Province will be interested to learn of the remarkable experimental work being carried out in a part of this area at Bamiaburu, some twenty miles distant from Chakardharpur on the Bengal-Nagpur Railway. The work so far undertaken has led to results of considerable importance, when it is mentioned that some five sixths of the Bihar forests consist of this worthless type of forest. Of greater value, however, is their apparent opportunity for experimental work on a wider basis in parts of the world where the activities of man are resulting in appalling floods and bad soil erosion.

Briefly, a scheme was commenced in 1933 at Bamiaburu with the object of arresting the run-off water from hillsides by making a system of contour channels. By this means the water percolates down through the soil instead of running to waste. This delayed run-off on an extensive scale would possibly prove a solution for flood problems, by permitting the plain's water, which in any event would be less in quantity, to get away first. As a result of this holding up of the water by the contour channels, remarkable growth is already becoming evident in areas where formerly hollow stagheaded droughtstricken trees prevailed; blanks are filling up with regeneration and the density of stocking is increasing. The cost of the work is low, Rs. 100 per mile only, if dry rubble bunds (walls) for crossing nullahs are made instead of something more expensive. Observations taken during the last year or two have shown that the night temperature in April in the area at present under treatment (height $1,250 \mathrm{ft}$.) under steady meteorological conditions was equivalent to that experienced at $3,000 \mathrm{ft}$. in these parts. Humidity and rainfall in May (1936), under disturbed atmospheric conditions were higher than at any other recording station nearby, though its situation and topography were less favourable than at one station. Clouds in the latter half of this month spread each evening over the areas, with the often purely local precipitation of rain. Additional light showers during the day fell only in the area itself, and not outside, and so were not recorded. Mr. Warren does not pretend to be a meteorological expert. No recording station with a similar situation to Bamia. buru exists in the neighbouring areas, and he had not the advantage himself of proper equipment. $\mathrm{He}$ therefore only summarizes actual experiences and records obtained. It is too early to claim too much from this remarkable experiment. But to those formerly acquainted with this, in April and May, torrid region, the results so far attained appear to open great possibilities.

That this contour-channel method is not a new idea, in India at least, is shown in an article by Dr. R. M. Gorrie, in the May issue of the Indian Forester, on that evergreen theme, the erosion in the Pabbi Hills in the Gujrat District in the Punjab. This problem is more than half a century old, the country having been taken over by the British in 1857, some attempts at regulating the grazing on this arid and already heavily eroded mass of foothills rising out of the plain being made about 1877. At this period the erosion was considered in connexion with the North Western Railway line. In the early 1880's reclamation and protection work were taken in hand by the late J. H. Lace. One of the methods introduced by Lace was trenching dug along the contours of steep slopes to catch and hold water for the use of tree seedlings on the berm.

Lace's work was successful, but Government soon let it drop, and the subsequent history of the Pabbi is depressing reading. What has forced the Pabbi erosion question to a head in modern times is the building of the Upper Jhelum Canal. This work is being affected to a serious extent by the enormous masses of silt brought down in the sudden floods, and considerable sums of money have had to be spent on protective works to the canal system from this cause alone.

\section{Scientific Tests of a Vaudeville Telepathist}

$\mathrm{B}^{\mathrm{V}}$ ULLETIN 3 of the University of London Council for Psychical Investigation consists of a detailed study by S. G. Soal of the hyper-acuity of the senses that is made use of by Josef Kraus ("Marion"), either consciously or unconsciously, in producing his demonstrations of telepathy and clairvoyance. The interest of this report is enhanced by the fact that it is the first scientific research into this subject, and it need scarcely be pointed out that the precautions that have to be taken when human beings are the material of the experiment far exceed those necessary in other branches of science. As an exposition of these precautionary measures alone, the Bulletin is quite outstanding and should be carefully studied by everyone interested in psychical research. In- cidentally, the facts disclosed in this research throw very grave doubt on the supposed proofs of telepathy and clairvoyance that have recently received considerable publicity, and in particular those of Dr. J. B. Rhine in the United States.

In Section 1, a statistical study of the results of experiment shows that Marion can rapidly locate small objects that have been hidden by a small audience who know the hiding-place and whose involuntary movements he is able to observe. Similarly, he can determine an imaginary hiding-place concentrated on by the audience when no actual object is hidden. But he cannot improve on chance results if the audience is screened from his view, or if no one in the room is consciously aware of the 
hiding-place. This indicates that he gets visual indications of small unconscious movements by one or more persons in the audience.

In another series of experiments, Marion exhibited a power superior to that of Cumberlandism or muscle-reading by finding hidden objects when followed by a single person who knew the hiding. place. Progressive covering up of this agent by a wooden box showed that Marion could still succeed even when he could see no more than the agent's feet. If the agent was totally covered and wheeled round the room, failure ensued. In this case slight changes in the movements of walking appear to be the principal indicia. This result clearly indicates that in any telepathic experiment the agent should not be visible to the percipient.
In Section 2, Marion's power of recognizing cards which he had previously handled, when mixed in a new pack, is studied, and it is shown that this is probably due to tactual discrimination of a high order. His departure abroad prevented experiments to see if he could emulate the blind osteopath, Captain Lowry, by distinguishing the pips on a playing-card by sense of touch alone.

Further statistical and other tests in telepathy and clairvoyance are described in Section 3; but no evidence was provided of any faculty for reading the contents of sealed envelopes or of divining numbers thought of by members of an audience. Marion's claims as regards graphology and psychometry also seem to be without foundation.

\section{Transatlantic Steam Navigation a Century Ago}

Jisi ST when the S.S. Sirius and the S.S. Great Western were being advertised to sail on their first passages to New York, and on the day, March 31, 1838, the Great Western left the Thames for the Severn, preparatory to starting on her voyage on April 8, the Athenceum published an article running to four pages under the title "Atlantic Steam Navigation". This was one of several articles in the same journal all of which were written with a good knowledge of the subject and in an unprejudiced manner. From the article which appeared in the issue of March 31, the following passages are taken :

"There is really no mistake then in this long talked of project of navigating the Atlantic Ocean by steam. There is no doubt, that is, of the existence of the intention to make the attempt, and to give the experiment, as such, a fair trial. Nor is the intention entertained (like many innovations sometimes more ingenious than will bear much examination) by an irresponsible party, or by one party alone, as we shall presently show. The whole commercial community, at least of our own country, and we may add of the United States, are alive to its interest. In Liverpool, New York and the 'Great Metropolis'-the three depots of the mercantile navigation of Christendom . . . the work goes bravely on. The Sirius is absolutely getting under weigh, while we write this paragraph, for America New York, via Cork! The buzz of excitement yesterday reached even the secluded walls of our own study. We rushed down to Blackwall pell-mell, in an omnibus, like all the rest to see not the Sirius but the Great Western, which the papers have told us so much about for a month past. . . Groups of nobility and gentry, with his Grace of Wellington at their head, figured in the cabin album; and we met as we came back, the Lord Mayor with his state carriage and four footmen rolling in gold, dashing down to Blackwall to get a last glimpse; all in pursuit, in a word, of the great animals of the day-the steamers now starting for the other side of the Atlantic.

"There is no mistake, then, we repeat, as to the trial of the experiment."

The writer of the article then went on to deal with the Sirius, the Great Western, the companies, the construction of the British Queen at Limehouse, the charges to be made for passengers and letters, the attitude of the Liverpool shipowners and other matters. "Our space," he concluded, "is now small for discussing anew the policy or subsequent prospects of this scheme. We consider it, however, in that view, a subject of very considerable importance, as well as of the most curious and teeming interest. If sustained, there can be no doubt of its vast advantage in speed. . . . For the mails, for the immense and vastly increasing correspondence between the two countries, for all personal intercommunication of mercantile men ... this is a vital and conclusive point. We must count also on an increase in travel. ling, if not of trade. . . .

"We think the sum of it, for the present, may be taken thus:--the practicability of steam will be established at once. Its speed and its certainty will induce interests, enough for its maintenance, to a greater or lesser extent to support it. All correspondence will be conveyed by it; all mercantile travel and some goods. Most passengers may be shy of it for a time-many for a long time (as some are of railroads still); accidents will happen of course; still the scheme will go on to maturity. Of its influence on other and far greater interests than yet alluded to, we cannot now speak. This is a scheme not to be hastily treated. It is one, too, which may be deferred awhile. All eyes now are turned on the "commencement of the end". We may yet discuss with improved data, the end of such a beginning."

The Great Western, the first steam vessel designed for the Atlantic passage, it may be added, was $212 \mathrm{ft}$. between perpendiculars, $35 \mathrm{ft}$. wide inside the paddle boxes and on a draught of $16 \mathrm{ft} .8 \mathrm{in}$. displaced 2,300 tons. Built of wood, she was strengthened in an elaborate manner by diagonal trussing of wood and iron and was copper sheathed. She had four boilers designed to work at $5 \mathrm{lb}$. pressure and her engines developed about 750 horse-power. Her machinery weighed nearly 400 tons and she stowed about 600 tons of coal. She left Blackwall early on March 31, 1838, and when she was between Gravesend and Southend a fire broke out around the base of the funnel which threatened to spread to the ship. The fire, however, was got under and the ship eventually left the Severn on her maiden voyage on April 8. 